\title{
A conclusão do juízo sobre Babilônia Interpretação em chave dialógico-litúrgica de Ap 19,1-10
}

Vicente Artuso

\section{Introdução}

O presente estudo sobre Ap 19,1-10 consta de uma tradução, crítica textual, análise literária e um comentário exegético seguido da hermenêutica.

$\mathrm{O}$ estudo da estrutura literária e da delimitação do texto irá mostrar que a perícope tem uma 'fisionomia identificável e classificável' (Ugo Vanni), com alguns elementos que a caracterizam com o gênero literário dialógicolitúrgico. Com efeito, o vocabulário litúrgico, a importância dos elementos literários da pornê (prostituta) e da gynê (mulher), o movimento temático do juízo realizado, passando para o anúncio da salvação escatológica antecipada, mostram a função da perícope como conclusão do juízo sobre babilônia, na forma de um canto de triunfo. A parte da exegese dos versículos vem sustentada por alguns comentários conhecidos por sua seriedade científica: Swete, Allo, Charles. Utilizamos com mais frequência as obras de Prigent, Vanni, Ruiz.

No âmbito deste trabalho, não nos é possível afrontar todos os problemas postos pela perícope, sobremaneira aqueles que dizem respeito aos vv. 9-10. No entanto, nosso estudo deixa entrever a riqueza do texto, sobre o qual existe muito ainda o que refletir e dizer. O leitor perceberá uma análise com chave dialógico-litúrgica, consoante com a linha de pesquisa do conhecido exegeta Ugo Vanni, professor do Instituto Bíblico de Roma. Na atualidade, os enfoques da pesquisa sobre o apocalipse, são diversificados. Por isso reconhecemos, a necessidade de uma complementação com outros 
autores recentes, para a análise do texto, sobretudo no aspecto narrativo no grande bloco literário do juízo sobre babilônia.

\section{Tradução de Ap 19,1-10}

19,1 Depois disto, ouvi como uma voz grande de uma multidão numerosa no céu dizendo:

Aleluia.

A salvação e a glória e a força (são) de nosso Deus,

19,2 porque verdadeiros e justos (são) os juízos dele, porque julgou a grande prostituta,

a qual corrompeu a terra com a sua prostituição, e vingou o sangue dos seus servos da mão dela.

19,3 E disseram uma segunda vez, aleluia; e a sua fumaça sobe pelos séculos dos séculos.

19,4 E caíram (prostrados) os vinte e quatro anciãos e os quatro viventes e adoraram a Deus que está sentado sobre o trono dizendo: amém aleluia.

19,5 E uma voz do trono saiu dizendo: Louvai o nosso Deus todos (vós) os seus servos, os que o temem, os pequenos e os grandes.

19,6 E ouvi como voz de uma multidão numerosa e como voz de muitas águas e como voz de fortes trovões dizendo: aleluia, porque reinou o nosso Deus, o onipotente.

19,7 Alegremo-nos e exultemos demos a ele glória, porque chegaram as núpcias do cordeiro e a sua mulher se preparou.

19,8 E foi dado a ela a fim de revestir-se de um linho resplandecente e puro; o linho de fato são as ações justas dos santos.

19,9 E disse-me: escreve; felizes os chamados para o banquete das núpcias do cordeiro; estas são as verdadeiras palavras de Deus.

19,10 E caí diante dos seus pés para o adorar, então ele me disse: "Ora, não"; sou um servo contigo e dos teus irmãos que têm o testemunho de Jesus; adora a Deus. De fato, o testemunho de Jesus é o espírito de profecia.

\section{Crítica textual}

O aparato crítico da $26^{\mathrm{a}}$ edição de Nestle-Aland assinala a presença de vinte e oito 'pontos vulneráveis' ${ }^{1}$. A maioria destas variantes se deve ao estilo espontâneo do autor que usa o limitado vocabulário do grego koiné, e muitas

\footnotetext{
${ }^{1}$ Denominação para as variantes cuja atestação é muito inferior à lição preferida, por isso são consideradas secundárias.
} 
vezes retoma, de modo sofisticado, do hebraico do $1^{\circ}$ e do $2^{\circ}$ século. Razão pela qual, não causam espanto as deficiências do texto, sobretudo "um grande número de vistosos solecismos devido ao descuido do autor na concordância" ${ }^{2}$. Apesar das incongruências próprias no uso da linguagem corrente do tempo (grego koiné) percebe-se que "o autor, embora não sendo um perfeito artista, é um escritor genial, que possui um raro poder de evocação capaz de atrair a atenção do leitor mesmo o mais distraído" ${ }^{3}$.

Muitos editores do texto, filólogos e exegetas, no decorrer da história tentaram ajudar nosso autor, fazendo 'oportunas' correções aqui e ali, aumentando e diminuindo o texto. Não faremos um estudo exaustivo de crítica textual, percorrendo todas as variantes propostas, pois a grandíssima maioria são apenas tentativas de intervenção no texto, correção da sintaxe ou do estilo do autor, mas que não influem decisivamente na interpretação do texto.

Vejamos as passagens disputadas que são de maior relevo.

Ap 19, 3: eirêkan - alguns minúsculos $(1854,2030)$ e Boharítica propõem a lição eirêken, que sintaticamente vai muito bem. O Códice Efhrain-Paris do séc. V propõe a forma regular do aoristo (eipan). Estas propostas pouco ajudam, pois o perfeito, no uso do grego tardio, tornou-se um simples tempo narrativo como o aoristo ${ }^{4}$, e nos papiros do $1^{\circ}$ séc d. C. o aoristo era somente usado com eireka no caso deste verbo ${ }^{5}$. A atestação em favor da variante eireken, a mais correta sintaticamente, é muito fraca. Além do mais uma mudança do gênero não influirá na interpretação da perícope.

V. 5: kai - atestado no Códice Alexandrino, nos unciais 046, 051, Siríaca, Vulgata e um grande número de minúsculos. Portanto, está bem documentada esta partícula. No entanto, kai está ausente no Sinaítico, no Efhrain-Paris, e no Códice Porphyrianus (séc IX).

A problemática que se põe é esta: a palavra foi acrescentada por copistas para evitar que o leitor interpretasse o grupo dos que temem a Deus como um grupo diverso de hoi douloi autou? Consideremos que existe um grande equilíbrio na evidência externa tanto pela manutenção de kai no texto quanto pela sua omissão ${ }^{6}$. Segundo a explicação do Professor Ugo Vanni, a

\footnotetext{
${ }^{2}$ BLASS-DEBRUNNER, Grammatica del Greco del Nuovo Testamento, § 136.

${ }^{3}$ ALLO, E. B., L'Apocalypse, 80.

${ }^{4}$ Cf. ZERWICK, M., Biblical Greek, § 289.

${ }^{5}$ Cf. BLASS-DEBRUNNER, Grammatica del Greco..., § 343.

${ }^{6}$ METZGER, B. M., A Textual Commentary on the Greek New Testament, 759.
} 
omissão se explica pela harmonização com a categoria que segue: hoi mikroi megaloi. Acrescentando kai, se obtém um alargamento de prospectiva: hoi douloi autou constitui a esfera celeste, enquanto kai hoi foboumenoi são os que estão no mundo ${ }^{7}$. É de se considerar também que a construção com kai vai muito de acordo com o estilo do Apocalipse (cf. Ap 11,18; 19,18; 20,12; 21,16).

Diante do equilíbrio, entre as propostas pro e contra a manutenção do kai no texto, as edições de Nestle-Aland e The Greek New Testament preferiram manter kai entre parêntesis quadrados, isto é, não se pode garantir sua pertença ao texto original.

V. 6: neste versículo, em vez de legontôn, o uncial 051 e os manuscritos de André de Cesaréia propõem legontas. Os minúsculos 1854, 2030 e um numeroso grupo de códices da koiné propõem legontes. Tais propostas são sintaticamente corretas; legontôn, porém, é largamente documentada e por bons testemunhos: Sinaítico, Alexandrino, Prophyrianus, Petrogarad, 0229, $1006,1611,1841,2053,2062,2329$. Seria tal forma apenas uma incongruência? Do ponto de vista da evidência externa, e mais por causa do estilo do autor, legontôn é a lição preferida, apesar de sua irregularidade.

Ainda neste mesmo versículo temos outro problema: a questão do pronome hêmôn. A variante com o pronome kyrios ho theos hêmôn tem uma atestação de peso e também geograficamente bem distribuída: Sinaítico duas vezes corrigido, Porphyrianus, Petrogard, 046, 1611, 1854, 2030, 2062, Vulgata, textos da koiné, etc. Outra variante hyrios ho theos, que omite o pronome, é documentada pelo Alexandrino, 1006, 1841 e manuscritos tipo André de Cesaréia.

O pronome hêmôn vem omitido porque inapropriado com a expressão kyrios ho theos ho pantrokratôr, pois nenhum dos outros exemplos desta expressão no Apocalipse vem acompanhado do pronome (cf. Ap 1,8; 4,8; $11,17 ; 15,3 ; 17,7 ; 19,1.5 ; 21,22)$. De fato, é difícil tomar uma decisão. Pelos motivos acima expostos e em vista da evidência externa, Nestle-Aland e The Greek New Testament preferiram manter hêmôn entre parênteses quadrados ${ }^{8}$. Já a edição de Merk o conserva no texto, sem qualquer observação.

V. 7: A observação a fazer neste versículo diz respeito à lição dôsômen, testemunhada apenas pelos minúsculos 2062, 2329 e um grupo de

\footnotetext{
${ }^{7}$ VANNI, U., Apocalisse: Esegesi dei Brani Scelti, Fasc. IV, 172.

${ }^{8}$ Cf. METZGER, B. M., A Textual..., 760.
} 
manuscritos do tipo André de Cesaréia. A lição dôsomen (futuro) é testemunhada pelo Sinaítico duas vezes corrigido, pelo Alexandrino, que é de grande valor para o Apocalipse, e pelo minúsculo 2053, testemunhos de maior peso do que a lição adotada pelo texto.

A lição dômen (conjuntivo) é testemunhada pelo Sinaítico de primeira mão, 051, uma série de minúsculos $(1006,1611,1841,1854,2030)$ e um grupo de códices do tipo koiné. É uma lição muito bem documentada e gramaticalmente correta. É difícil considerá-la original por causa da evidência de outras variantes. A lição dôsomen (futuro), embora atestada, é intolerável depois de dois subjuntivos exortativos. A lição que prevaleceu no texto de Nestle-Aland e The New Testament foi dôsômen, considerada a menos insatisfatória. A edição de The New Testament, porém, coloca-a entre parêntesis com a letra $\mathrm{D}$, isto é, com grandíssimo grau de dúvida .

A edição crítica de Tischendorf (1869-1872) e a edição de Merk preferem a lição dômen. Von Soden prefere o futuro dôsomen, que é a lectio dificilior. A opção por qualquer uma das três lições não parece interferir, significativamente, na interpretação do texto.

Entre as passagens disputadas, uma - kai hoi foboumenoi (Ap 19,5) tem importância para a interpretação do texto, como já analisamos anteriormente. Todas as outras passagens, por mais estudadas que sejam pelos críticos, tem importância para a sintaxe ou para o estilo, mas não alteram o conteúdo de nossa perícope.

\section{Delimitação do texto}

Nossa perícope (Ap 19,1-10) é enquadrada na secção conclusiva do Apocalipse $(16,17--22,5)$ que trata do juízo e condenação de Babilônia ${ }^{10}$. Os estudiosos estão de acordo em considerá-la como uma solene conclusão do grande julgamento.

Vemos claramente, que existe uma passagem para uma nova temática em 19,1 com meta tauta, expressão de transição, e o verbo êkousa, indicando que algo novo vem narrado pelo autor e proposto ao grupo de ouvintes. Em 19,11 o autor passa da audição para a visão, fenômeno típico do Apocalipse: kai eidon. Começa então a narração de um combate imaginário, cuja descrição se apóia totalmente na frase do v. 11: kai idou hiptos leukos kai ho kathêmenos ${ }^{11}$.

\footnotetext{
${ }^{9}$ Cf. METZGER, B. M, A Textual..., 760.

${ }^{10} \mathrm{Cf}$. VANNI, U., Note Introdutorie All'Apocalisse, 3.

${ }^{11}$ Cf. VANNI, U., La Struttura Letteraria dell'Apocalisse, 202ss.
} 
Pode-se individuar a perícope mais precisamente pelos seguintes elementos ao interno do texto:

a) a recorrência das proclamações litúrgicas do Allêlouia de forma intercalada, fato único no Apocalipse, o que confere ao texto uma tonalidade solene, contrastante com o tom sombrio e obscuro do cap. 18.

b) enquanto nossa perícope se refere a proclamações, diálogo litúrgico - ao menos nos vv. $1-8^{12}$ - a perícope seguinte $(19,11 \mathrm{ss})$ vai falar de ações celestes; c) em relação à perícope anterior, vemos ainda uma mudança de cenário: celestial e litúrgico, com a introdução de novos personagens. Veremos, com maior precisão, os elementos que caracterizam a unidade de nossa perícope na secção seguinte.

\section{Análise literária}

\subsection{Gênero literário dialógico-litúrgico}

A primeira constatação, ao ler o texto, é sua articulação sobre o motivo literário do Allêlouia, que aparece quatro vezes no texto (vv. 1.3.4.6) ${ }^{13}$. O vocabulário cúltico, as formas litúrgicas e doxológicas, acompanhadas de prostração e adoração (v. 4) caracterizam o gênero literário litúrgico dos vv. 1-8.

Aqui são satisfeitas as condições do gênero dialógico-litúrgico: quatro interlocutores ou grupos de atores são nomeados e envolvidos no drama litúrgico: uma voz que ressoa do céu como a de uma multidão (vv. 1-2 e um segundo tempo no v. 3); o coro combinado dos vinte e quatro anciãos e os quatro viventes (v. 4, última vez em que aparecem no Ap); uma voz do trono (v. 5) e uma voz como a voz de uma imensa multidão, semelhante ao fragor das grandes águas e o som poderoso do trovão (vv.6-8).

A antifonal qualidade desses versículos emerge quando João narra no v. 3 que ouviu o primeiro coro uma segunda vez, e então ouve a afirmação enfática dos vinte e quatro anciãos e dos quatro viventes no v. 4. Então uma voz do trono proclama uma exortação de louvor (v. 5), a qual é entusiasticamente obedecida nos vv. 6-8. Ap 19,1-8 é qualificada, pois, como um diálogo litúrgico não somente porque há vários atores dirigindo-se uns aos outros, mas porque isto acontece de uma maneira estilizada, quase antifonal, própria de uma adoração pública, e, por causa disso, o que os personagens dizem nesta celebração é

\footnotetext{
${ }^{12}$ Os vv. 9-10 parecem fora de lugar, pois rompem a continuidade dramática quando se faz a conexão do v.8 com o v.11. Não obstante isso, como veremos, são fortes os motivos para considerar Ap 19,1-10, no seu todo, como a conclusão do juízo sobre Babilônia.

${ }^{13}$ Cf. VANNI, U., La Struttura..., 164.
} 
doxológico. O mesmo gênero literário é reencontrado também em Ap 1,4-8 e $22,6-21)^{14}$.

\subsection{O movimento temático}

Vejamos agora qual é a temática que está por trás deste drama litúrgico e como vem apresentada. Desde o início, esta celebração litúrgica comporta uma progressão intencional ${ }^{15}$. Esta progressão segue o movimento temático da doxologia. O primeiro coro (vv.1-3) canta o castigo de Babilônia, a grande meretriz, já realizado nos capítulos 17-18. Isso é evidenciado pelo motivo literário pornês, que, neste caso, serve de motcrochet, recorrente em Ap 17,1.5.15.16. É um "terminis a quo", um ponto de partida que tende a um desenvolvimento, a uma conclusão.

O segundo coro (vv.6-8) canta as núpcias do Cordeiro numa atitude prospectiva de futuro ${ }^{16}$, pois o motivo literário numphên faz referência ao triunfo da esposa, o qual acontecerá em seguida, na descrição da Jerusalém Celeste (Ap 21,2).

O motivo primeiro da doxologia é o louvor a Deus. No primeiro coro (vv.1-3), Deus é louvado porque (hoti) justos e verdadeiros são os seus julgamentos (v.2). No segundo coro, porque (hoti) tomou posse do seu reino o Senhor onipotente (v.6b). Vem, então, o segundo hoti (v.2.7) que, em ambos os casos, é subordinado ao primeiro, e constitui o motivo particular do louvor, pois o especifica e o particulariza ${ }^{17}$.

A esse ponto, o desenvolvimento do drama litúrgico revela a estreita ligação literária entre os vv.1-3 e os vv.6-8, pelo paralelismo existente entre os dois coros.

\subsection{Paralelismos}

Nota-se os paralelismos entre os vv. 1-2 e os vv. 6-8. Tem-se aqui dois coros. Cada coro contém uma afirmação que diz respeito à figura feminina sobre a qual a atividade divina se concentra. 19,2 descreve os delitos da Grande Prostituta, enquanto 19,7-8 fala dos atos de justiça pelos quais a Esposa do Cordeiro se prepara. Cada coro segue cantando uma ação divina apropriada ao comportamento da figura feminina descrita. 19,2 louva a Deus por vingar o sangue dos seus servos contra a Grande Prostituta. Usando o

\footnotetext{
${ }^{14}$ RUIZ, J. P., Ezekiel in the Apocalypse..., 483-484

${ }^{15}$ PRIGENT, P., L'Apocalisse di S. Giovanni, 558.

${ }^{16}$ Cf. VANNI, U., La Struttura..., 164.

${ }^{17}$ RUIZ, J. P., Ezekiel in..., 494.
} 
passivo teológico (edothê), 19,8 descreve o hábito privilegiado com o qual Deus assegurou que a Esposa seria revestida. Em 19,2 a Grande Prostituta é punida; em 19,8 a Esposa recebe sua recompensa.

Embora não seja aconselhável falar aqui de um paralelismo estreito, alguns pontos de contato literário revelam a clara intenção, por parte do autor, de relacionar os dois coros:

a) Aclamação: allêlouia - 19,1.6

b) Motivo geral de louvor: 19,2: pela verdade e justiça dos julgamentos; 19,6: porque o Senhor nosso Deus, o Poderoso, estabeleceu seu reino;

c) Motivo particular de louvor: 19,2: porque foi julgada a Grande Prostituta; 19,7: porque chegaram as núpcias do Cordeiro;

d) Figura feminina e sua conduta: 19,2: a Grande Prostituta corrompeu a terra com a fornicação; 18,7: a Esposa do Cordeiro se aprontou;

e) Resposta divina à conduta da figura feminina: 19,2: vingou o sangue dos servos contra Grande Prostituta; 19,8: foi concedido à Esposa de vestir-se em linho esplendente.

Assim apresentados, esses elementos ilustram o movimento da retrospectiva dos primeiros versículos de Ap 19 e apontam para a doxologia que encerra a perícope. Os dois momentos não coincidem completamente: em 19,3 o coro celeste profere uma segunda aclamação - 'a fumaça dela se eleva para sempre' - recordando-nos que a Prostituta vencida é uma entidade sócio-política; em19,8b o coro recorda que as núpcias do Cordeiro com sua Esposa não são um casamento comum: vê-se da explicação de como foi feito o vestido de noiva: as obras dos santos ${ }^{18}$.

Os vv.4 e 5 constituem o ponto de junção entre os dois coros. "São um inserimento de uma cena litúrgica que descreve ainda uma vez a adoração da corte celeste"19. $^{11}$. O v. 4 conclui o $1^{\circ}$ coro com o Amen Allêlouia dos vinte e quatro anciãos e os quatro viventes que adoram a Deus sentado no trono. O v. 5 introduz o $2^{\circ}$ coro (vv.6-8) pela voz que parte do trono e convida ao louvor. Thronos e Theos são as palavras que fazem a junção na parte central da doxologia, isto é, entre os vv. 1-3 e 6-8. Vemos a correspondência entre a adoração a Deus (v.4) e o louvor a Deus (v.5). No primeiro caso os anciãos e os quatro animais se prostram diante do trono; no segundo caso, a voz sai do trono ${ }^{20}$.

Nota-se também que os vv. 9-10 estão em estreito paralelismo com 22,69. Num contexto mais largo, fecham a visão que começa em Apc 17,1 sob o título "O Julgamento da Grande Prostituta". Para a nossa perícope $(19,1-10)$ não

\footnotetext{
${ }^{18}$ RUIZ, J. P., Ezekiel in..., 495-6.

${ }^{19}$ CORSINI, E., Apocalisse prima o dopo, 581.

${ }^{20}$ BULLINGER, E. W., Commentary on Revelation, 581.
} 
parece criar problemas. No v. 9a a palavra do anjo que ordena (grapson) dá garantia à mensagem, pois uma vez que o autor viu $(17,1)$ e ouviu $(19,1)$ deverá comunicar o que recebeu, por escrito ${ }^{21}$.

A bem-aventurança dos convidados ao festim das núpcias do Cordeiro provê a transição da doxologia (vv. 1-8) e integra o banquete escatológico com o tempo da salvação cristologicamente focalizado, identificado com as núpcias de $19,7-9^{22}$.

A ligação desta bem-aventurança com a imagem nupcial da última parte da doxologia (v.8), a associação de prostração com adoração em estreito paralelismo com 19,4, a função de alethinoi em 19,9 como mot crochet com 19,2 (onde aparece alethinai) e o fato que pornên em 19,2 tem uma função retrospectiva com relação aos capítulos 17 e 18 são motivos suficientes para considerarmos os vv. 9-10 como epílogo, não somente da doxologia final $(19,1-8)$, mas de toda a secção dedicada ao juízo sobre Babilônia ${ }^{23}$.

Vimos que Ap 19,1-10 é uma perícope articulada com elementos do culto litúrgico e por isso tem uma estrutura doxológica ${ }^{24}$. Em geral tais estruturas fogem a uma classificação esquemática precisa; não é o caso de nossa perícope, cujos elementos se concatenam de tal modo que atingem uma harmonia na qual se entrevê uma disposição paralela dos elementos tipo A B C A' B' C'.

Em nosso caso, o mais importante não é descobrir uma disposição simétrica, mas perceber a estilizada maneira como a "transição literária, partindo da prostituta, da besta e de Babilônia, passa para a esposa, o cordeiro e a nova Jerusalém. Tal transição reflete a confiança na vitória final do Senhor, à qual o autor convida seus destinatários a participar ${ }^{25}$.

\subsection{Plano da perícope}

Feitas estas observações, de ordem literária e estilística, propomos o seguinte plano:

$1^{\mathrm{a}}$ Parte - Doxologia: vv. 1-8

a) $1^{\circ}$ Coro: v. 1-3

v. 1: proclamação do louvor pela multidão.

v. 2a: motivo geral do louvor e sua descrição.

v. 3: segundo tempo da proclamação.

${ }^{21}$ RUIZ, J. P., Ezekiel in..., 504 e 526.

${ }^{22}$ RUIZ, J. P., Ezekiel in..., 509.

${ }^{23}$ PRIGENT, P., Apocalisse..., 571.

${ }^{24}$ Cf. RUIZ, J. P., Ezekiel in..., 496.

${ }^{25}$ Cf. RUIZ, J. P., Ezekiel in..., 496. 
b) secção intermediária: vv. 4-5

v. 4: resposta dos anciãos e dos quatro viventes como ênfase à conclusão do $1^{\circ}$ coro.

v. 5: convite ao louvor como introdução ao segundo coro.

c) $2^{\circ}$ Coro: vv. $6-8$

v. 6a: proclamação do louvor a Deus pela multidão.

v. $6 \mathrm{~b}$ : motivo geral do louvor.

vv. 7-8: motivo particular do louvor e descrição.

$2^{\mathbf{a}}$ Parte - Epílogo - vv. 9-10

a) v. 9a: a ordem de escrever.

b) v. 10a: afirmação da veracidade da palavra.

v. 10b: explicação do anjo.

c) v. 10c: o testemunho de Jesus e do Espírito de Profecia.

\section{Comentário exegético}

Ap 19,1 - meta tauta: é uma expressão comum no Apocalipse $(1,19$; $4,1 ; 7,9 ; 9,12 ; 15,5 ; 18,1 ; 19,1 ; 20,3)$. Exprime comumente uma transição literária que indica um desenvolvimento, sempre em estreita ligação com o que precede; em nosso caso se liga aos capítulos 17 e 18. Destarte, de uma parte, indica a grande unidade literária de 17,1-19,11; de outra parte, precisa as várias fases da mesma unidade ${ }^{26}$.

O verbo êkousa (eu ouvi) significa aqui ouvir no sentido físico; o verbo, porém, também significa 'entender' e 'acolher' o objeto da audição. A seqüência visão-audição é típica do Apocalipse. Toda a perícope que estamos analisando está construída sob o ouvir, pois se trata de um canto celebrativo solene.

...hôs phônên megalên ochlou pollou: '... como uma voz grande de uma multidão numerosa' - com a partícula hôs, o autor mostra a sua reserva na descrição do que ouviu. Trata-se de uma visão na esfera celeste, onde qualquer tentativa humana de descrição é relativa.

Phônên corresponde a $q w l$ em hebraico, significando 'voz' 'som', 'rumor', algo bem definido, portanto. Nos escritos apocalípticos phônê, foi bastante determinado pelo uso lingüístico do AT. Pelo contexto se entende como expressão vocal de uma multidão, em forma de júbilo, para exaltar os grandes feitos de Deus ${ }^{27}$.

Quem é esta multidão numerosa?

\footnotetext{
${ }^{26}$ Cf. VANNI, U., Apocalisse, Esegesi dei Brani Scelti, fasc. VI, 163.

${ }^{27}$ KITTELL, Grande Lessico del Nuovo Testamento, vol XV, 287.
} 
A maioria dos autores pensa que seja composta de anjos, os mesmos que participaram ativamente nas liturgias precedentes. Um bom grupo de intérpretes (Bousset, Allo, Kraft) é do parecer que esse coro celeste inclua também os cristãos. Prigent também é a favor de não exclusivizar esta multidão como sendo simplesmente dos anjos, pois os cristãos, especialmente os mártires, formam também um coro celeste (Ap 7,9) e suas proclamações de louvor não são diferentes ${ }^{28}$.

...en tô(i) ouranô(i) legontôn ${ }^{29}$ : '... que diziam no céu'. A grande multidão que proclama no céu obedece ao convite em Ap 18,20: "Alegrai-vos, ó céus!". Conforme Ugo Vanni, esta multidão se situa na esfera da transcendência, e coincide com os habitantes da Nova Jerusalém (cf. 21,1-22,5), que na antecipação lírica da celebração se supõe já realizada ${ }^{30}$. O caráter celebrativo foge a categorias comuns de tempo. Passado, presente e futuro estão incluídos no momento da liturgia.

...allêlouia, 'aleluia' - esta é a primeira ocorrência da palavra Aleluia no Novo Testamento. É a palavra hebraica composta (hll-yh), que significa: 'Louvai a Javé'. Aparece vinte e quatro vezes no AT, e quatro no Novo, todas elas curiosamente no livro do Apocalipse (Ap 19,1.3.4.6)

Tal exclamação foi, provavelmente tomada da sinagoga Helenística pela Igreja apostólica e aplicada na liturgia como Hosana. Tornou-se muito familiar mesmo para os cristãos iletrados ${ }^{32}$. Aleluia é um convite de tonalidade evidentemente litúrgica, própria dos salmos de louvor (S1 104106; 110-112, 113-118, 134-135, 145-150, segundo a edição dos Setenta), com particular ligação com o culto e com as festas principais. Aqui a aclamação não parece inserida organicamente no discurso celebrativo; tem uma função paralela.

...hê sôtêria kai hê doxa kai hê dynamis tou Theou hêmôn, 'A salvação e a glória e a força (são) de nosso Deus' - estes atributos de Deus, como também no v. 2, devem ser considerados como explicação da palavra Aleluia. A Ele

\footnotetext{
${ }^{28}$ PRIGENT, P., L'Apocalisse..., 551.

${ }^{29}$ Legontôn aqui é um acordo ad sensum, em vez de legontos, que seria mais apropriado (cf. ALLO, E. B., L'Apocalypse, 274).

${ }^{30}$ Cf. VANNI, U., Apocalisse, Esegesi dei Brani Scelti, fasc. VI, 163.

31 BULlinger, E. W., Commentary..., 584, faz uma observação interessante sobre a ocorrência do Aleluia: No AT, em sete Salmos, uma vez: S1 104,35; 105,45; 111,1; 112,1; 125,$18 ; 126,2$. Em mais sete Salmos, duas vezes: Sl 106,1.48; 113,1.9; 146,1.10;147,1.14; $149,1.9 ; 150,1.6$. Três vezes em um Salmo: S1 135,1.3.21, perfazendo um total de vinte e quatro vezes, ou duas vezes doze, o dobro do governo divino sobre a terra. Se juntarmos as quatro vezes do Apocalipse $(19,1.3 .4 .6)$ temos vinte e oito vezes, ou quatro vezes sete, ou seja, perfeição espiritual com relação à terra

${ }^{32}$ Cf. SWETE, H. B., The Apocalypse of St. John, 242.
} 
se deve o louvor acima de todas as coisas. Os três atributos se referem à sua ação na história. Força e glória são às vezes mencionadas juntas no Novo Testamento (Mt 6,13; Col 1,11; IITess 1,9). A glória é manifestação da força e da salvação de Deus na história e sobretudo em Cristo e na sua obra redentora (Mt 17,2ss; Jo 1,14). São atributos estreitamente relacionados um ao outro e são tou theou hêmôn. Esta expressão se refere ao Deus da Aliança, a qual se revela como plenamente realizada, antecipando o que será explicitado em Ap 21,3.

Ap 19,2: hoti, 'porque' - trata-se de um hoti declarativo que constitui a passagem literária da consideração de Deus em si mesmo com os atributos que lhe competem (cf. 19,1), ao seu contato com a história ${ }^{33}$.

...alêthinai kai dikaiai hai kriseis autou, 'verdadeiros e justos (são) os seus juízos'. O significado de alethinai reproduz exatamente aquele hebraico de ' $m t$, 'seguro, válido, vinculante'. Ap 19,2 começa justamente por repetir a aclamação encontrada em 16,7, depois do derramamento da $3^{\text {a }}$ taça: "Justos e verdadeiros (são) os seus julgamentos". Este louvor a Deus motivado pela qualidade dos seus julgamentos reflete a influência de Dan 3,27. Deus manifesta a retitude dos seus julgamentos em Ap 16,17-19,10, condenando a iniqüidade de Babilônia $(18,5)^{34}$.

...hoti ekrisen tên pornên tên megalên, 'porque julgou a prostituta, a grande'. O segundo hoti, como já referimos ao tratar da estrutura da perícope, é subordinado ao primeiro porque explicita em que consistem os julgamentos de Deus. Passa-se da atenção a Deus à sua ação na história. Aqui é uma referência clara ao julgamento da grande prostituta nos capítulos 17 e 18 . ekrinen significa, neste contexto uma sentença de condenação: Deus decretou a destruição total de Babilônia.

...hêtis ephtheiren tên gên en tê(i) porneia(i) autês, 'a qual corrompeu a terra com a sua prostituição'. Como é indicado pelo sentido do verbo ephtheiren, trata-se da corrupção moral de toda a humanidade. É o que fez a meretriz, já corrompida em si mesma pela sua depravação moral, corrompeu também toda a humanidade: "O homem velho se corrompe moralmente nas suas paixões e conforme a essas" (Ef 4,22), e acaba gerando um modo de vida depravado. Assim, toda a terra também é corrupta e violenta diante de Deus (cf. Gn 6,11). Destruir e corromper são os sentidos deste verbo para caracterizar a ação nefasta daqueles que arrastam o povo longe dos caminhos da obediência e da consagração a Deus. Prostituição se entende como

\footnotetext{
${ }^{33}$ VANNI, U., Apocalisse, Esegesi dei Brani Scelti, fasc. VI, 164.

${ }^{34}$ RUIZ, J. P., Ezekiel..., 488.
} 
idolaria e, num sentido mais geral, qualquer rebelião à vontade de Deus ${ }^{35}$. Portanto, um atentado contra toda a humanidade.

... kai exedikêsen to haima tôn doulôn autou ek cheiros autês, 'e vingou o sangue dos seus servos da mão dela'. Vemos como o autor retoma o vocabulário forense do Apocalipse (cf. 16,7; 17,1; 18,20): julgamento, julgar, vingar. Isso para ilustrar a ação de Deus na história, o qual julga e condena a grande meretriz que engloba em si mesma as forças do antiCristo. O verbo que aqui aparece (ekdikeo) se encontra também em Ap 6,10. Nessa passagem "ouve-se o interrogativo impelente e a súplica dos mártires para a vingança, isto é, para o juízo final. Não vem acolhida imediatamente. Permanece um espaço de tempo, de tal modo que a vingança, purificada de qualquer revanche humana, vem deixada a Deus, e sua realização vem anunciada somente em 19,2"136.

O tema da vingança e retribuição, neste versículo já foram tratados em 18,6-8; aqui, porém, é retomado o que foi omitido em 18,24 , i.e., a vingança dos profetas e santos que são os servidores de Deus. Em 18,24 o sangue encontrado em Babilônia é sinal irrefutável de seus crimes ${ }^{37}$.

Ap 19,3 - kai deuteron eirêkan allêlouia, 'e disseram uma segunda vez: aleluia'. Lê-se no texto grego 'segundo', neutro sem o nome. Como 'voz' no v. 1 é feminino, e 'multidão' é masculino, é difícil afirmar com exatidão o que ou quem é este 'segundo' ${ }^{\prime 38}$. É mais uma entre as muitas irregularidades do autor. De qualquer forma, entende-se que uma segunda vez disseram Aleluia. A repetição serve para enfatizar a celebração litúrgica e a temática que esta comporta.

...kai ho kapnos autês anabainei eis tous aiônas tôn aiônôn, 'e a sua fumaça sobe pelos séculos dos séculos'. Em toda a sessão do julgamento de Babilônia (16,17-19,10), a metáfora do mau comportamento sexual é aplicada em 19,2-3 para caracterizar o comportamento de uma entidade sócio-política. Isso é bem ilustrado em 18,9, onde se diz que os reis da terra, que com ela se prostituíram, se lamentarão quando verão a fumaça do seu

\footnotetext{
${ }^{35}$ Cf. PRIGENT, P., L'Apocalisse..., 345.

${ }^{36}$ FALKENROTH, U., 'ekdikeo', in: Dizionario dei Concetti Biblici del Nuovo Testamento, 1479-80.

${ }^{37}$ RUIZ., J. P., Ezekiel..., 489: pode-se ver nesta vingança um influxo de IIRe 9,7: Deus vinga o sangue dos seus profetas e servos da mão de Jezabel, ou seja, de tudo o que Jezabel fez a eles (SWETTE, PRIGENT). RUIZ mostra como a figura de Jezabel ajuda a entender a figura de Babilônia, a cidade-prostituta como uma entidade sócio-política.

${ }^{38}$ FORD, J. M., Revelation, 309.
} 
incêncio. Para o coro celeste, a fumaça que sobe aos céus é visível evidência da vitória divina ${ }^{39}$. 'Pelos séculos dos séculos' é uma expressão que se refere ao tempo da história da salvação, e não necessariamente a uma duração ao infinito na linha de nosso tempo atual. Trata-se de um ato de julgamento que entra na esfera da transcendência, e Deus mesmo dá a garantia absoluta desta destruição ${ }^{40}$.

Ap 19,4: kai epesan hoi presbyteroi hoi eikosi tessares kai ta tessara zô(i)a, 'e caíram (prostrados) os vinte e quatro anciãos e os quatro viventes'. Os vinte e quatro anciãos, junto com os quatro viventes, constituem uma figura complexa no Apocalipse ${ }^{41}$. Neste texto, última vez em que aparecem no Apocalipse, eles são mediadores, entendidos como progredidos na esfera da transcendência, e que podem ajudar a multidão terrestre a alcançar também o mesmo nível. A participação deles nesta celebração evidencia ainda mais a tonalidade litúrgica. Em outros textos, especialmente nos capítulos 4 e 5 do Apocalipse, sempre aparecem em estreita conexão com o louvor dirigido a Deus criador e redentor. Pode-se dizer que os vinte e quatro anciãos e os quatro viventes manifestam um vivo interesse pela história humana, são solidários com os cristãos fiéis e vencedores, enquanto são uníssonos a estes no mesmo louvor de aprovação pelos feitos do Senhor ${ }^{42}$.

kai proskynêsan tô(i) theô(i) kathêmenô(i) epi tô(i) thonô(i) legontes amên, allêlouia, 'e adoraram Deus que está sentado sopre o trono dizendo: amém, aleluia'. O verbo proskyneo (59 vezes no NT, das quais 29 no Ap) significa 'pôr-se em atitude de adoração', sendo objeto desta adoração unicamente Deus. Nenhum outro ser pode pretender esta prerrogativa: "Adorarás a Deus e só a ele servirás", responde Jesus às insídias do diabo (Mt 4,10).

Deus sentado no trono, mostra que o vidente está experimentando uma visão de trono. Esta expressão indica a superioridade absoluta de Deus sobre o mundo. É ele que dirige e determina os rumos da história. Em Ap 5,6ss se diz que no meio do trono - o que significa 'no centro do juízo divino sobre o mundo' - aparece aquele que preside: o Cordeiro imolado.

\footnotetext{
${ }^{39}$ Cf. RUIZ, J. P., Ezekiel..., 492.

${ }^{40}$ VANNI, U., Apocalisse, Esegesi dei Brani Scelti, fasc. VI, 167.

${ }^{41}$ VANNI, U., Apocalisse, Esegesi..., fasc. III, 85-86, apresenta (p.86) um elenco de possíveis explicações sobre a figura dos vinte e quatro anciãos: 1) seres celestes (Boismard, Bousset, Allo); 2) homens glorificados (Ticônio, Lutero, Beda, etc.); 3) os santos da Antiga e Nova Aliança (A. Magno); 4) personagens do AT (Prigent, Feuillet); 5) toda a humanidade (Renan, Ragaz, Guardini).

${ }^{42}$ Cf. PRIGENT, P., L'Apocalisse..., 555-556.
} 
Os anciãos e os quatro viventes diziam: amém, aleluia. $\mathrm{O}$ amém é o 'assim seja' litúrgico. Em seguida vem acrescentado o aleluia que, no caso, expressa a confiança em Deus que está agindo na história. Tudo é aceito pelos anciãos e pelos quatro viventes; tudo vem considerado como realizado, pois a salvação, a glória e a força, manifestadas na história pelas intervenções de Deus, interessam a todos os homens que estão sobre a terra, em favor dos quais os anciãos e os viventes são mediadores.

Ap 19,5: kai phônê apo tou thronou exêlthen legousa: aineite tô(i) thô(i) hêmôn, 'e uma voz do trono saiu que dizia: louvai o nosso Deus'. Pelo sentido do verbo exelthen, 'saiu', a voz não provém simplesmente do trono, mas sai do trono e ressoa por toda a terra para que todos escutem. Com este verbo, muito freqüente no Apocalipse $(6,3 ; 14,15.17 .18 ; 15,16 ; 16,17)$, vem indicada a passagem da transcendência para a imanência ${ }^{43}$. Quem fala? provavelmente é um mensageiro autorizado na corte celeste. A voz, por um lado, indica uma reação de resposta ao que os anciãos e os viventes disseram; por outro lado, enquanto convida ao louvor, introduz o segundo coro que começa no v. 6. 'Louvai o nosso Deus' é uma exortação ao louvor calcada no Salmo 135, 1.20: "Louvai o nome do Senhor, louvai, ó servos do Senhor". Isso justifica o uso do verbo aineo com o dativo em vez do acusativo, que seria mais comum. Uma vez que ainein reproduz o idioma hebraico $h w d h$ lyhwh é provável que o autor fosse influenciado por esta expressão quando escreveu ${ }^{44}$.

pantes hoi douloi autou, 'todos (vós) seus servos', indica o conjunto dos fiéis como em Ap 1,1; 2,20; 7,3, incluindo os santos apóstolos, profetas $(1,1 ; 10,7$; $11,18 ; 22,6)$ e mártires $(7,3 ; 19,2)$. O contexto deve decidir sua especial significação. Aqui se trata de todos os fiéis.

kai hoi phoboumenoi auton, hoi mikroi kai hoi megaloi, 'e todos aqueles que o temem, os pequenos e os grandes'. Como vimos na crítica textual, por causa da partícula kai, temos aqui a dificuldade de precisar os destinatários da exortação. Os servos do Senhor e os que temem formam dois grupos distintos ou um grupo só? Apesar da indecisão de nossas edições modernas sobre a originalidade do $k a i$, a tendência é de conservá-lo no texto. kai tem um significado mais de insistência que de enumeração distintiva. $\mathrm{O}$ autor não se preocupava em distinguir categorias de fiéis dentro da Igreja ${ }^{45}$. Pode-se entender o kai ainda com a função de especificar a totalidade dos servidores do Senhor: os seus servos que estão no céu $k a i$, e também os que estão na terra, grandes e

\footnotetext{
${ }^{43}$ VANNI, U., Apocalisse, Esegesi dei Brani Scelti, fasc. VI, 169.

${ }^{44}$ CHARLES, R. H., The Revelation..., vol. II, 124.

${ }^{45}$ Cf. PRIGENT, P., L'Apocalisse..., 257.
} 
pequenos $^{46}$, ou seja, gente de todos os níveis de cultura, de todas as classes sociais e de progresso na vida cristã ${ }^{47}$.

Ap 19,6: kai êkousa hôs phonên ochlou pollou, kai hôs phônên hydatôn pollôn kai hôs phônên brontôn ischyrôn, 'e ouvi como voz de uma multidão numerosa e como uma voz de muitas águas e como voz de trovões potentes'. Este versículo marca o início do segundo coro cantado pela Igreja universal ${ }^{48}$ como resposta à exortação no v. 5: 'Louvai o nosso Deus'. Novamente o autor fala com sua habitual reserva de sua experiência de visão ${ }^{49}$. A partícula hôs, à diferença do v.1, desta vez descreve com alguns detalhes a voz desta multidão, mostrando que se trata de um coro muito mais potente do que o do v. 1. Este ampliamento insistente é propositado da parte do autor, e revela neste ponto que a doxologia está chegando ao seu auge ${ }^{50}$.

Como já observamos no v. 1, phonê corresponde ao hebraico qwl, 'rumor, som'. Este texto, com seus paralelos no Apocalipse (cf. 1,15; 14,2; $6,1 ; 10,3)$ é caracterizado pelo influxo do AT. $q w l$, raramente com o artigo no plural absoluto, é o som do trovão (cf. Ex 9,23.29.33; 19,16; ISam 12,17). Em nosso texto, phonê é precisado com o genitivo, como é comum no AT (cf. Sl 42,8; 93,3; Ez 37,7) ${ }^{51}$. Esta voz que por si mesma é a voz da grande multidão, com essas precisações - como voz de trovão e de grandes águas chega a ter características próprias da voz de Deus. Isto insinua que a multidão no louvar a Deus, pode fazer o timbre da voz divina ${ }^{52}$.

Legontôn allêloui, 'que diziam: aleluia'. A queda de Babilônia, o inimigo que parecia imbatível, já é um presságio da salvação consumada que terá lugar no estabelecimento definitivo do Reino. Não é ainda o estabelecimento total, pois haverá outras lutas contra a besta $(19,11 \mathrm{ss})$, mas já é garantia do poderio do Senhor. Por isso a multidão pode repetir Aleluia, em resposta ao canto dos anciãos e dos viventes ${ }^{53}$.

hoti ebasileusen kyrios ho theos hêmôn ho pantokratôr, 'porque reinou o Senhor nosso Deus, o Onipotente'. O canto dos novos cristãos vv. 6 e 7 chega à sua plenitude, pois celebra o Senhorio de Deus Salvador. hoti ebasileusen é uma expressão carregada de significado bíblico e reflete o

\footnotetext{
${ }^{46}$ Cf. VANNI, U., Apocalisse, Esegesi dei Brani Scelti, fasc. VI, 172.

${ }^{47}$ Cf. SWETE, H. B., The Apocalypse..., 244.

${ }^{48}$ SWETE, ALLO, PRIGENT são de acordo em que é o povo cristão, a Igreja toda que está cantando.

${ }^{49}$ MORRIS, L, Revelation, 217.

${ }^{50}$ Cf. PRIGENT, P., L'Apocalisse..., 558.

51 cf. KITTEL, R., Grande Lessico del Nuovo Testamento, vol XV, 287.

${ }^{52}$ VANNI, U., Apocalisse, Esegesi dei Brani Scelti, fasc. VI, 172.

${ }^{53}$ ALLO, E. B., L'Apocalypse, 275.
} 
estilo dos salmos de entronização (S1 93,1; 97,1; 99,1). O verbo aqui deve ser entendido como um aoristo ingressivo, para indicar uma ação começada em algum ponto do passado, iniciando uma condição que continua no presente. Portanto, indica o aspecto escatológico do fato: "O Senhor reina". O estabelecimento do Reino, no fim dos tempos, é a nova temática do nosso texto, o qual oferece uma doxológica antecipação desse mesmo reino ${ }^{54}$.

Apesar de haver bons motivos para omitir hêmôn do texto (cf. a crítica textual), preferimos mantê-lo, para entendermos melhor que o Deus onipotente é o Deus da Aliança, o qual se empenha com sua onipotência em favor do seu povo, para a realização do Reino.

Ap 19,7: chairômen kai agalliômen kai dôsômen tên doxan autô(i), 'alegremo-nos e exultemos e demos sempre a ele glória'. A combinação desses dois verbos se encontra em outros textos do NT (Mt 5,12; Jo,8,16; $1 \mathrm{Pd} 1,8 ; 4,13)$. Junto com a alegria vem a sua manifestação externa. agallein significa 'tornar esplêndido, decoroso'. No AT denomina a alegria cúltica que festeja e celebra a ajuda de Deus e as suas obras. No NT (Mt 1; Lc 2; Jo 2; 1Pd 3; Ap 1), exceto Jo 5,35, o verbo indica sempre uma exultação relacionada com as obras de Deus e se refere em particular ao cumprimento escatológico (Mt 5,12; 1Pd 4,13; Ap 19,7), onde Deus se revela como salvador de uma maneira inicial ou definitiva ${ }^{55}$.

O homem reage exultando. É o que faz a Assembléia litúrgica em nosso texto: alegra-se e exulta. Esta exultação é relacionada com a obra salvífica de Deus: o estabelecimento do seu Reino que vem especificado na celebração das núpcias do cordeiro.

hoti êlthen ho gamos tou arniou, 'porque chegaram as núpcias do cordeiro'. O segundo hoti introduz uma série de motivações paralelas ao primeiro. Especialmente introduz o motivo particular do louvor: a concretização desse reino na metáfora das núpcias do cordeiro. to arnion aparece no Apocalipse mais de vinte vezes. Em 16,17-19,10 o cordeiro é mencionado apenas quatro vezes. Além das duas ocorrências coligadas com as núpcias, to arnion aparece em 17,14. Nesse texto, a besta, com dez chifres, está empenhada em combater contra o cordeiro, mas este sai vencedor por que é o Senhor dos senhores. Trazendo o cordeiro em nosso texto (19,7b.9), o autor retrata a tensão entre a besta e o cordeiro no coração do contraste entre os dois grupos de motivos aparentados: Prostituta-besta-Babilônia; Esposa-Cordeiro-Nova Jerusalém. Na batalha entre as duas soberanias, o cordeiro sai vitorioso. Cristo, o Cordeiro, é a figura central no estabelecimento do Reino

\footnotetext{
${ }^{54}$ Cf. RUIZ J. P., Ezekiel..., 497-98.

${ }^{55}$ Cf. KITTEL, R., Grande Lessico..., vol I, 54.
} 
escatológico de Deus. Enquanto a figura do cordeiro fornece um enfoque cristológico do Reino escatológico de Deus, sua dimensão eclesial é sugerida pela figura da mulher. Em nosso texto, a mulher $(19,7)$ é a antítese da mulher dos cc. 17 e 18 . No c. 17 a grande prostituta é ligada com a besta e é atraída pelo colorido dos seus adornos; enquanto a mulher em 19,7 é a esposa ligada com o esposo que é o cordeiro. Esta é atraída pelos adornos e vestes que o próprio esposo lhe deu ${ }^{56}$ e não apenas pelos seus. Portanto, o Reino de Deus se atua neste nível de amor de Cristo pela Igreja, semelhante ao amor entre esposo e esposa celebrado nas núpcias.

kai hê gynê autou hêtoimasen heautên, 'e a sua mulher se preparou'. É uma expressão cara ao autor $(12,6 ; 16,12 ; 21,3)^{57}$. Significa que, no decurso da história, a Igreja vai preparando seu hábito de esposa pelas próprias ações do povo de Deus ${ }^{58}$, entre as quais as obras dos santos e dos mártires que lavaram suas vestes no sangue do cordeiro $(7,14)$. Neste período de preparação os cristãos são vistos como a nymphê, 'a noiva' (cf. 22,17) que aspira ser a esposa. Esta imagem das núpcias se faz presente no AT onde Israel é considerado a esposa de Javé (Is 54,6; Ez 16,8; Os 2,14). Nos evangelhos (Mt 22,2; 25,1; Mc 2,19) e no Apocalipse, onde parece quatro vezes (Ap 19,9; 21,2.9;22,17), é a figura apropriada para expressar a intimidade e indissolubilidade da comunhão de Cristo com a comunidade que ele resgatou com seu sangue (cf. Ap 6,9; 7,17; 14,1) ${ }^{59}$.

Ap 19, 8: kai edothê autê(i) hina peribalêtai byssinon lampron kai katharon, 'e foi dado a ela de revestir-se de um linho resplandecente e puro'. O verbo edothe é um passivo teológico que supõe Deus como agente ativo. 'Foi dado' indica a parte de Deus na obra da redenção, num paralelismo sinonímico com a ação da mulher que se prepara por si mesma (v.7), indicando a cooperação humana. 'Foi-lhe dado de revestir-se de linho puro e resplandecente' - distingue-se claramente entre linho, sua pureza e seu esplendor. Este tipo de linho se refere à ação de justiça dos santos. Portanto, esta veste dos santos cristãos, confeccionada cada dia na história por graça de Deus, torna-se a veste da esposa, no esplendor das transcendências ${ }^{60}$.

\footnotetext{
${ }^{56}$ RUIZ, J. P., Ezekiel..., 498-499.

${ }^{57}$ Pelo contexto, a tradução de gynê por 'noiva' em vez de 'mulher' é mais apropriada, pois o texto está falando da preparação imediata para as núpcias (cf. JEREMIAS, J., TDNT 4. 1099$1100)$.

${ }^{58}$ Cf. VANNI, U., L'Apocalisse, Ermeneutica..., 258.

${ }^{59}$ Cf. CHARLES, R. H., Revelation, vol II, 126.

${ }^{60}$ Cf. VANNI, U., L'Apocalisse, Ermeneutica..., 258: o verbo periballo aparece doze vezes no Apocalipse, principalmente acompanhado de himation (cf. 3,5.18; 4,4) ou stolê (cf 7,9.13). A veste é um fato antropológico de importância. O autor pensa no homem inserido na história,
} 
Trata-se, em outras palavras, do corpo celeste, transfigurado, do qual todos seremos revestidos, com a condição de chegarmos já vestidos das boas obras, e não nus (cf. $2 \mathrm{Cr} 5,1-5)^{61}$.

to gar byssinon ta dikaiomata tôn hagiôn estin, 'o linho de fato são as ações justas dos santos'. Com esta expressão o autor quer ajudar a comunidade ouvinte a interpretar adequadamente o símbolo apresentado antes. $\mathrm{O}$ autor quer insistir no significado da frase 'foi-lhe dado revestir-se'. O fato de que Deus é o doador da veste não implica que esta veste seja recebida passivamente pelas pessoas, totalmente alheias aos seus compromissos. Devem exprimir os seus atos de justiça - dikaiômata em contraposição com adikemata de Babilônia - (Ap 18,5) mediante seu esforço, suas obras ${ }^{62}$.

Ap 19,9: kai legei moi grapson makarioi hoi eis to deipnon tou gamou tou arniou keklêmenoi, 'e me disse: escreve: "Felizes os convidados para o banquete das núpcias do cordeiro"'.

Quem fala é provavelmente o anjo intérprete, o qual interveio em Ap 17,1 para introduzir a visão da grande prostituta, e em Ap 17,7ss para dar as explicações $^{63}$. $\mathrm{O}$ anjo na apocalíptica tem uma função de mediação entre o nível de Deus e aquele do autor. A intervenção diz respeito à ação do autor, que é escrever. Naturalmente, se trata de um escrito para ser lido na assembléia litúrgica $^{64}$. O uso do imperativo grapson sublinha a importância daquilo que João deve escrever. Onze vezes aparece no Apocalipse a ordem de escrever: 1,1; $2,1.8 .12 .18 ; 3,1.7 .14 ; 14,13 ; 19,9 ; 21,5$. Em cada ocorrência, ao escrever o autor obedece a um explícito mandato divino. A referência às palavras de profecia $(1,3)$ e às "proféticas palavras deste livro" (22,7.9.10.18.19) torna evidente que o livro do Ap constitui o cumprimento da missão profética de João. Ele deve comunicar estas palavras, e nisto está implícita sua missão profética de escrever para que o seu trabalho possa ser lido e entendido pela comunidade (cf. Ap 1,3; $22,7.9)^{65}$.

visualizando-o, dando-lhe uma relevância para que o próprio homem, na sua experiência, descubra que é destinado ao Reino escatológico.

${ }^{61}$ Cf. CHARLES, R. H., Revelation, vol. I, 184.

${ }^{62}$ Cf. PRIGENT, P., L'Apocalisse..., 259.

${ }^{63}$ Cf. PRIGENT, P., L'Apocalisse..., 564.

${ }^{64}$ VANNI, U., L'Apocalisse, Ermeneutica..., 267.

${ }^{65}$ Cf. RUIZ, J. P., Ezekiel..., 506-507: a concepção do ministério profético de João e seu produto: um livro escrito, resultado da sua familiaridade com a profecia bíblica como literatura profética. O Apocalipse faz extensivo uso da linguagem cunhada na profecia bíblica. Por exemplo, a imagem profética do casamento de Javé com Israel (Os 2,19; Is 61,10; 54,5-6; Ez $16,8)$ é largamente usada em nosso texto. 
O conteúdo da obra a ser escrita é a quarta bem-aventurança do Apocalipse (ao todo são sete as bem-aventuranças: Ap 1,3; 14,13; 16,15; $19,9 ; 20,6 ; 22,7 ; 14,13)$. Em Ap 14,13 o macarismo se refere aos mortos, que morrem no Senhor, e gozam do repouso eterno. Aqui a reflexão passa da noção de repouso àquela muito mais rica da participação no banquete escatológico.

É interessante observar a semelhança desta bem-aventurança com Lc 14,15: "feliz aquele que comerá o pão no reino de Deus". Somos tentados a pensar que o autor conhece estes textos evangélicos e usa a palavra 'chamados' no mesmo sentido que os evangelhos, os quais contrapõem-na a 'eleitos'. Segundo Prigent, deve-se traduzir keklêmenoi como 'convidados'. O ponto essencial é afirmar a realidade do convite: os 'chamados', que são também os 'eleitos', os 'fiéis' $(\mathrm{Ap} \mathrm{17,14)}$ não podem responder senão positivamente ao convite ${ }^{66}$.

kai legei moi houtoi hoi logoi alêthinoi tou Theou eisin, 'e disse-me: "Estas são as verdadeiras palavras de Deus"'.

Como existe um estreito paralelismo entre Ap 19,9b-10 e 22,6-9, Bousset, Charles e outros supõem que este texto (v. 9b-10) seja apenas uma repetição aqui introduzida secundariamente. Isso em parte é verdade; não temos, porém, explicações plausíveis, por que o autor teria feito esta inserção. Certo é que Ap 22,6-9 estende a garantia às palavras de todo o livro. Por que pois este solene atestado de autenticidade viria repetido no texto $?^{67}$ Qual seria a extensão do livro incluída nesta garantia? no mínimo abrange as palavras da bem-aventurança. Lohmeyer sustenta que esta garantia abrange os capítulos 17 e 18. Esta posição parece justificável por causa dos paralelismos destes dois versículos com a doxologia (cf. o capítulo anterior do nosso trabalho sobre a estrutura de Ap 19,1-10) e sua função retrospectiva.

A frase de que estamos tratando - 'estas são as verdadeiras palavras de Deus' - pode ser compreendida de dois modos:

a) estas são as palavras mesmas de Deus, ou

b) estas palavras, que são de Deus, são verdadeiras. Em ambos os casos, a fórmula soa como uma conclusão, por seu caráter enfático. No Apocalipse se diz que Deus é verdadeiro - alêthinos - (Ap 6,10), como o é também Cristo (Ap 3,7.14; 19,11) e as várias ações de Deus (Ap 15,3; 16,7; 19,2); assim, também as suas palavras são verdadeiras.

\footnotetext{
${ }^{66}$ PRIGENT, P., L'Apocalisse..., 564.

${ }^{67}$ Cf. RUIZ, J. P., Ezekiel..., 508-509.
} 
Ap 19,10: kai epesa emprosthen tôn podôn autou proskynêsai kai legei moi: hora mê, 'e caí diante dos seus pés para o adorar, mas ele me disse: "Não faças isso!"'68.

$\mathrm{O}$ autor, que é o próprio vidente, reage às palavras do anjo, assumindo uma postura de adoração, caindo diante de seus pés em reverência. epesa proskynêsai é uma fórmula fixa no Ap. Exceto em 19,10 e 22,8, significa 'prostração para adorar a Deus' feita pelos participantes da liturgia celeste (em Ap 4,10; 5,8 apenas epesa: 5,14; 7,11; 11,16; 19,4). Estas ocorrências precedem imediatamente as doxologias proclamadas por aqueles que se prostram. A ocorrência desta forma, especialmente em 19,4 em estreito paralelismo com 19,10a, indica que o aparente engano do vidente ao prostrar-se diante do anjo foi para mostrar que unicamente a Deus se deve a adoração. João usa o seu próprio engano e a correção do anjo para chamar a atenção dos seus ouvintes, convidando-os a refletir sobre a imagem apresentada. Este procedimento, com a intervenção do anjo intérprete, aparece também em 17,7$18^{69}$.

Um aspecto importante a considerar é o paralelismo entre 19,10 e 22,8-9. A repetição da tentativa de o vidente adorar o anjo e a consequente correção do anjo intérprete mostram ao menos a intenção de insistência na adoração a Deus. Este parece ser o motivo forte desta mensagem duplicada. Em geral os comentadores (Allo, Bousset, Swete e outros) explicam que se trata de uma polêmica dirigida contra o culto dos anjos bastante difuso na Ásia Menor. Col 2,18 é, com freqüência, citado como evidência que tal problema existia. Portanto, era necessário corrigir os desvios. Prigent apresenta muitas dúvidas quanto à consistência do problema da adoração dos anjos ${ }^{70}$. Mounce diz ser muito improvável que o objetivo da repetição de tais versículos seja o desencorajar a tentação de adorar anjos. É difícil imaginar o vidente esperando por uma oportunidade, para prostrar-se ele mesmo diante do anjo, para ensinar seus leitores que somente Deus é digno de adoração ${ }^{71}$. Mesmo se a adoração aos anjos fosse um problema, isto não seria suficiente para explicar a extensão do paralelismo entre 19,9-10 e 22,6-9 $9^{72}$. Esta é uma face do problema. A disputa

\footnotetext{
${ }^{68}$ A repetição desta tentativa de adoração, por parte do vidente em 22,8-9, é algo estranho. João, uma vez que recebeu a correção do anjo, por que iria voltar a cometer o mesmo erro?

${ }^{69}$ Cf. RUIZ, J. P., Ezekiel..., 511-512.

${ }^{70}$ Cf. PRIGENT, P., L'Apocalisse..., 585.

${ }^{71}$ MOUNCE, R., The Book of Revelation, 341.

${ }^{72}$ RUIZ, J. P., Ezekiel..., 512: sendo que 19,9-10 constitui uma garantia para os capítulos 17 18 , a questão por que João tenta homenagear o anjo uma segunda vez perde a sua urgência. Além do mais a função parenética desta 'adoração' de João ganha maior ênfase.
} 
maior está na parte final do v. 10: a interpretação de martyria Iesou, que veremos a seguir.

sundoulos sou eimi kai tôn adelphôn sou tôn echontôn tên martyrian Iêsou tô(i) Teô(i) proskynêson. hê gar martyria Iêsou estin to pneuma tês prophêteias, 'sou um servo contigo e teus irmãos que têm o testemunho de Jesus. Adora a Deus. O testemunho de Jesus é o espírito da profecia ${ }^{13}$.

$\mathrm{O}$ anjo se apresenta como um companheiro de João, um servidor com ele em uma missão específica. O anjo explica, e João escreve, o que a assembléia deve aprender. Sendo ambos servos do mesmo Deus, resulta claro que o imperativo tô(i) teô(i) proskynêson dirigido a João vale também para todos os outros que têm o testemunho de Jesus. Justamente nesta frase, cuja expressão martyria Iêsou vem explicitada na frase seguinte, está o cerne de toda a problemática. martyria Iêsou tem sido explicada como um genitivo objetivo, isto é, 'testemunho sobre Jesus', ou como genitivo subjetivo, indicando o testemunho dado por Jesus. Swete tenta combinar as duas interpretações: o testemunho de Jesus é o espírito de profecia, ou seja, a posse do espírito profético, o qual torna verdadeiro um profeta, e se faz visível numa vida que dá testemunho de Jesus, o qual perpetua seu testemunho do Pai e de si mesmo. Na prática as duas coisas são idênticas: os verdadeiros profetas são testemunhas de Jesus, e quem tem o testemunho de Jesus, no seu mais pleno significado, são os $\operatorname{profetas}^{74}$, pois "ninguém pode dizer 'Senhor Jesus' senão no Espírito Santo"' (1Cor 12,3).

Charles considera a primeira frase - martyria Iêsou - como genitivo subjetivo com base em Ap 1,2, onde 'palavra de Deus' e 'testemunho de Jesus' são colocados no mesmo nível. Sendo assim, trata-se claramente de um genitivo subjetivo porque o testemunho de Jesus é igual à totalidade da revelação que Deus faz de si mesmo pela sua palavra. A segunda frase, porém, - martyria Iêsou - deve ser entendida como 'o testemunho sobre Jesus'. Seguese que a partícula gar deve ser tomada com sentido explanatório: 'assim pois o testemunho sobre Jesus é o Espírito de profecia'. Neste sentido a declaração do anjo significa que ele é companheiro de João e daqueles que partilham com ele o espírito profético ${ }^{75}$. Portanto, o genitivo aqui é considerado como

\footnotetext{
${ }^{73}$ Optamos por esta tradução porque aceitamos a interpretação de martyria Iêsou como um genitivo subjetivo; do contrário, escolheríamos a tradução proposta por Petros Vassiliadis: "What ispires the prophets is that they can witness (even unto death) to Jesus" (cf. The Translation of 'martyria Iêsou' in Revelation, The Bible Translation, vol 36(1) 1985, 129-134).

${ }^{74}$ Cf. SWETE, H. B., The Apocalypse..., 249.

${ }^{75}$ Cf. CHARLES, R. H., Revelation, vol II, 130. M. Ford sugere tratar-se aqui de uma sucinta referência ao retorno da profecia como sinal da nova aliança com Jesus como Senhor (cf. The Testimony of Jesus in the Spirit of Profecy, ITJ, 42(1975), 291.
} 
objetivo. G. W. H. Lampe ${ }^{76}$, após rever a interpretação de antigos e modernos exegetas sobre a interpretação deste versículo, conclui que se trata de um genitivo objetivo. Segundo sua interpretação, a ação do espírito de profecia se identifica com a confissão de Jesus feita em tempos de perseguição. Assim, as palavras echein martyrian (Ap 6,9;12,17; 19,10) significam 'manter firme o testemunho', paralelo à idéia contida em Ap 3,8: "Permaneça em minha palavra e não renegue".

Da mesma opinião é Petros Vassiliadis ${ }^{77}$ : estuda a problemática partindo de uma análise do desenvolvimento semântico do grupo de palavras martyria, martyrein, martys e conclui: "No Apocalipse a expressão martyria Iêsou sempre tem uma nuance martirológica. Ser testemunha de Jesus Cristo, mesmo até o martírio, é o que inspira os profetas". Tal como Orígenes define, para este autor martuse é igual a martírio.

Fred Mazzaferri ${ }^{78}$ procede com o mesmo método de análise do campo semântico usado por Vassiliadis para provar, porém, que os dois genitivos deste versículo são subjetivos. Mostra que martys nem sempre significa 'mártir', mas antes, profeta. Em Ap 1,2, texto já comentado, martyria Iêsou, junto com logos tou Theou, aparece duas vezes. Em 22,9 o anjo repete estas mesmas palavras com uma mudança: o particípio echontôn torna-se tôn prôphêtôn. Também aqui o testemunho de Jesus equivale à profecia.

O autor ainda observa que martyria lêsou está em aposição com logos tou Theou (Ap 1,2.9; 20,4). Isto significa que todo o livro de João é profético e que todos devem acolhê-lo como pessoal testemunho de Jesus, a viva voz do Espírito.

Portanto, martyria Iêsou é virtualmente o testemunho pessoal de Jesus e o testemunho do Espírito. Cada uma das cartas endereçadas às igrejas de fato conclui com a designação de Jesus ti to pneuma legei (Ap 2,7.11.17.29; 3,6; 13,22). Embora em Ap 19,10 João muda a ênfase do Espírito para o seu pessoal testemunho através da profecia, a cláusula final poderia ser parafraseada assim: profecia é inspirada por Jesus e pelo Espírito igualmente, e quando é proclamada torna-se testemunho do mesmo Jesus e do mesmo Espírito $^{79}$.

Em conclusão, é difícil determinar se o testemunho de Jesus deva ser tomado objetiva ou subjetivamente. É provável que ambos sejam verdadeiros.

\footnotetext{
${ }^{76}$ LAMPE, G. W. H., The Testimony of Jesus is the Spirit of Profecy, 247.

${ }^{77}$ VASSILIADIS, P., The Translation of 'martyria Iêsou' in Revelation, 129 e 130.

${ }^{78}$ MAZZAFERRI, F., 'Martyria Iêsou' Revised, 120,121.

${ }^{79}$ Cf. MAZZAFERRI, F. 'Martyria Iêsou' Revised, 120.
} 
Considerando que os autores modernos tendem para a interpretação como genitivo subjetivo, optamos por esta posição sem excluir a validade da outra.

Se entendermos como genitivo subjetivo, a mensagem que Jesus deu, seu testemunho do Pai, é o espírito o coração de toda profecia. Se entendermos como genitivo objetivo, o significado é que o verdadeiro espírito de profecia se manifesta no fato de alguém ser testemunha de Jesus numa entrega total, incluindo o martírio ${ }^{80}$.

São dois significados que não se excluem: o testemunho dado por Jesus (sentido subjetivo) torna-se testemunho sobre Jesus (sentido objetivo) dado por aqueles que são testemunhas, e particularmente pelos profetas cristãos ${ }^{81}$.

\section{Reflexão hermenêutico-teológica}

A reflexão hermenêutico-teológica torna possível a passagem do nível abstrato de uma mensagem ao nível de assimilação vital ${ }^{82}$. Veremos os temas mais destacados do texto estudado para iluminar a caminhada da comunidade eclesial que hoje lê e interpreta o Apocalipse.

\subsection{A celebração do Senhorio de Deus na História}

O domínio de Deus, que dirige os destinos da história, é o motivo principal do louvor. Como Deus fez de Israel seu povo, assim escolheu como sua propriedade os crentes em Cristo como geração eleita e povo santo (At 15,14; 20,28; Hb 11,25). É Deus o objeto da fé (Rm 4,3; Gl 3,6); a Ele a esperança e o louvor. A comunidade não deve ter outros ídolos, mas servir a Ele, cumprir sua vontade e manter-se fiel. Ele é o criador, conservador e senhor do mundo (At 17,24; Ap 10,6), arquiteto do universo ( $\mathrm{Hb} 3,4)$. Ele exercita o seu domínio do céu: "O céu é seu trono e a terra é o escabelo de seus pés" (Mt 5,34; 23,22); Ele é onipotente e justo ao qual nada é impossível (Mc 10,27).

O Deus que a comunidade deve celebrar é o Deus da aliança, que atua na história dos homens com seu poder salvador; por isso, "a Ele, salvação, glória e poder, porque justos e verdadeiros são os seus julgamentos" (Ap 19,12-). O passado e o futuro da ação de Deus são revividos no presente da liturgia: a escatológica sentença contra a grande Babilônia é celebrada como um fato consumado. Na liturgia, a obra perfeita da salvação se anuncia, ganha significado e se realiza: na assembléia é que as pessoas ocupam, perfeitamente, o lugar que lhes é reservado; é onde os adoradores reconhecem, no Deus único e

\footnotetext{
${ }^{80}$ Cf. MORRIS, L., Revelation, 222.

${ }^{81}$ Cf. RUIZ, J. P., Ezekiel..., 515.

${ }^{82}$ VANNI, U., L'Apocalisse, Ermeneutica, Esegese..., 19.
} 
verdadeiro, o poder de tudo criar e recriar. A comunidade, reconhecendo os atributos do Deus da aliança, como comunidade que lê os sinais dos tempos confrontando-os com sua palavra, não vacilará, porque sabe em que pôs a esperança. Somente à luz da fé será possível atribuir a ele qualquer conquista ou vitória, e perseverar no 'bom combate', mesmo quando parece evidente o triunfo do inimigo.

\subsection{A salvação e vitória contra o poder do mal}

A história caminha rumo a uma conclusão, mas o seu caminhar é do tipo dialético: se realiza na luta entre o Bem e o Mal. Isso acontece no plano individual e no plano coletivo. No centro desta dialética está Deus, senhor absoluto da história, aquele que está sentado sobre o trono, isto é, o que detém o controle sobre os acontecimentos. Nosso texto mostra que Deus é juiz, e o julgamento das potências do mal é definitivo $(19,3)$. Uma vez por todas, Babilônia foi destruída. O elemento, de triunfo e salvação vem expresso num canto de vitória. A salvação é vitória, por isso a multidão pode cantar exultante ${ }^{83}$.

O juiz é ao mesmo tempo salvador. O juízo é proclamado contra os maus já quando rejeitam o salvador; os bons, por sua vez, são livres da condenação. A intervenção salvífica de Deus, na qual são reassumidos todos os seus juízos precedentes sobre o povo eleito, no qual ele empenhou toda a sua vida, é o juízo pronunciado no evento da cruz. Com o anúncio da 'palavra da cruz' se revela definitivamente a ira de Deus ( $\mathrm{Rm} \mathrm{1,3).} \mathrm{E} \mathrm{Cristo} \mathrm{é}$ para a ruína e a ressurreição de muitos $(\operatorname{Lc} 2,34)^{84}$.

O juízo punitivo traz em si divisão (Jo 3,19), aniquilamento $(\mathrm{Hb}$ 10,27). Quem escuta as palavras de Jesus e nele crê não será julgado (Jo 5,24); mas todos os que fizeram o mal ressuscitarão para a condenação eterna (Jo 5,29).

Quando as pessoas reconhecem a Deus como salvador, se convertem em testemunhas do juízo. É o que acontece em nossa perícope. No culto, a revelação de Deus se atualiza, sendo que Deus é celebrado na terra, como salvador, como Rei e, portanto, como juiz.

\subsection{O reino escatológico}

A destruição das forças do mal não é a última palavra para os cristãos envolvidos no combate: Deus estabeleceu o seu reino $(19,7)$. O ponto de

\footnotetext{
${ }^{83}$ VANNI, U., Apocalittica in Nuovo Dizionario di Teologia Bilica, 104.

${ }^{84}$ COTHENET, E., Les écrits de Saint Jean et l'Epitre aux Hébreux, 259.
} 
chegada da história da salvação é aqui revelado. As forças histórico-sociais negativas são anuladas pela ação da presença ativa de Deus. Deus conduz a sua criação à consumação e leva à sua meta a história da humanidade. $\mathrm{O}$ canto de júbilo com que a Igreja se havia unido ao hino de ação de graças do céu, está no futuro para os destinários do Apocalipse. Para eles o canto é, por ora, unicamente expressão da esperança em que vivem e pela qual estão dispostos a dar a vida. Por esta causa, a visão antecipada da consumação se conclui declarando: "Felizes os convidados para o festim das núpcias" (Ap 19,9). A promessa trata de suscitar confiança e resolução para enfrentar os tempos de perseguição.

\subsubsection{A metáfora das núpcias do Cordeiro.}

Esta imagem remonta, originariamente, a uma representação dos profetas do AT, os quais enfocam a relação de Deus com o povo da aliança, por analogia do homem e da mulher em matrimônio (cf. Is 54,57; 62,4; Ez 16,7; Os 2,4-25). Jesus também utilizou de várias maneiras a imagem do banquete nupcial para representar a salvação consumada (Mt 22,2-4; 25,113; Lc 12,36; Jo 3,29). A relação pessoal que Deus tem com os eleitos é comparável à comunhão do esposo com a esposa (cf. 2 Cor 11,2; Ef 5,2533). Já neste mundo, a comunidade dos cristãos experimenta este amor fiel de Deus nas suas ações salvíficas na história. Tais ações, porém, são apenas uma imagem que preanuncia o reino futuro.

Tanto as núpcias, como o banquete, expressam a qualidade da vida determinada pelo reino de Deus. A abundância de alimento e bebida faz experimentar a riqueza dos bens escatológicos. As núpcias são o sinal da fertilidade de uma nova ordem em que não haverá mais destruição ou morte, mas a abundância de todos os bens. A comunidade deve manter-se vigilante, preparando-se com as boas obras para o festim das núpcias eternas na consumação do reino ${ }^{85}$.

\subsection{A Profecia}

No Ap 19,10 lemos: "O testemunho de Jesus é o espírito de profecia". Profetizar é deixar falar e atuar em nós o Espírito de Deus que através dos profetas do AT anunciavam a vinda de Jesus e seu testemunho. Assim, pois, profetizar é descobrir a intenção das antigas profecias para seguir o caminho daqueles profetas, o caminho do testemunho de Jesus. Ap 11 ilustra esta

${ }^{85}$ Cf. COLLINS, A.Y., The Apocalypse, 131-132. 
equivalência entre profecia e testemunho: não há referência ao conteúdo da pregação das duas testemunhas, mas vem descrita com detalhe sua morte e ressurreição. O essencial parece ser sua morte no Senhor $(11,18)$ e sua ressurreição em termos que evocam Cristo. Portanto, são apresentadas testemunhas, ou seja, pessoas que não hesitam em seguir o seu mestre, 'a testemunha fiel' (Ap 1,5) até a morte, como Antipas, a testemunha fiel $(\mathrm{Ap} \mathrm{2,13})^{86}$.

A parte final de nossa perícope (19,9-10), paralela com Ap 22,8-9 tem um caráter profético. Em ambos os casos a revelação transmitida pelo anjo foi dada em realidade por Deus $(19,9)$; a transcrição da revelação adquire, pois, a forma de uma profecia $(22,7)$. Assim, esta palavra de Deus se pode resumir em ambos os casos em uma bem-aventurança: "Felizes os convidados para o banquete das núpcias" $(19,9)$. Felizes os que guardam as palavras proféticas deste livro $(22,7)$. O Apocalipse se pode resumir em uma bem-aventurança, e esta é destinada aos fiéis seguidores de Cristo, suas testemunhas, os profetas.

O objetivo do Apocalipse é profetizar, ou seja, atualizar o testemunho de Jesus mediante o testemunho dos cristãos. A missão profética da Igreja é necessária. O plano de Deus não alcança seu cumprimento enquanto a Igreja, que lê e interpreta a palavra, não tenha respondido à sua vocação de ser para o mundo testemunha de Jesus.

\section{Conclusão}

Ao concluir este estudo convém destacar os seguintes pontos:

\section{a) Unidade do texto}

Embora do ponto de vista literário, os vv. 9-10 pareçam fora de lugar, rompendo a continuidade dramática, quando se faz a conexão entre o v. 8 e o v. 11 a perícope apresenta uma unidade pelos seguintes motivos: o gênero literário dialógico-litúrgico, constatável pela ocorrência de vocabulário cúltico-litúrgico, a intercalação das vozes que respondem ao convite ao louvor, os movimentos de prostração; o movimento temático que revela um crescendo até chegar a um ponto máximo; o paralelismo existente especialmente nos vv. 1-8 e mesmo nos vv. 9-10.

Existe, por conseguinte, uma estrutura doxológica bem articulada com o 'aleluia' em contraste com os 'ais' do cap. 18. Esta estrutura sugere que os destinatários do livro de João - a assembléia litúrgica - são ativos participantes na interpretação do livro e no drama que ele descreve, e não simplesmente ouvintes desatentos e alheios aos fatos.

${ }^{86}$ COTHENET, E., Les écrits de Saint Jean..., 245-248. 


\title{
b) A função literária
}

$\mathrm{Na}$ secção conclusiva do Apocalipse (16,17-22,5), 19,1-10 deve ser considerado como conclusão do juízo sobre Babilônia; ao interno da perícope, porém, existem elementos de ligação com o cap. 21: os vv. 1-2 têm uma função retrospectiva referindo-se à condenação da grande prostituta, o que é evidenciado pelo elemento literário pornê, que faz a ligação com os cap. 17-18. Os vv. 7-8 têm uma função prospectiva referindo-se ao triunfo da 'esposa', a realização escatológica do reino no cap. 21; e o elemento literário que faz esta ligação é a gynê, a mulher que é a esposa do cordeiro, a nova Jerusalém.

Os vv. 9-10 parecem fora de lugar, quando na verdade servem como epílogo, na forma de um solene atestado de autenticidade dos vv. 1-8, e, principalmente de toda a secção do juízo de Babilônia, iniciado em 17,1. Este mesmo atestado de autenticidade é repetido em 22,6-9, abrangendo todo o livro do Apocalipse.

c) Alcance teológico do texto

Trata-se de uma importante perícope do Apocalipse, cuja função, no contexto, engloba temas teológicos de relevo para todo o livro, tais como: o senhorio de Deus na história, o julgamento final, o reino escatológico acenado na metáfora das núpcias do cordeiro, a salvação, a Igreja, a profecia.

\begin{abstract}
The conclusion of the judgement over Babel.

Interpretation in the key liturgical dialogy of Apocalypse 19,1-10

Ap 19,1-10 is a hymn with a kind of literary liturgy. The vocabulary of worship/cult, the liturgical forms accompanied by prostration and adoration characterize the text. It's detaching the themes of God's Lordship, salvation, the victory against evil, the eschatological kingdom, and lastly the prophecy.
\end{abstract}

Vicente Artuso

Doutor em Teologia Bíblica pela PUC-Rio Professor no Programa de Pós-Graduação em Teologia na PUCPR - Curitiba; e na Graduação em Teologia - Campus-Londrina-Pr 


\section{Bibliografia Consultada}

ALAND, K. et al., The Greek New Testament, United Bible Societies, Münster/Westphalia, $1975^{3}$.

BLASS, F., DEBRUNNER, A., Grammatik des neutestamentlichen Griechisch; trad. it. Umberto Mattioli e Giordana Pisi: Grammatica del Greco del Nuovo Testamento, Paideia, Brescia, 1982.

KITTEL, G., FRIEDRICH, G., Theologisches Woerterbuch zum Neuen Testament, W. Kohlhammer, Stuttgart; trad. ing. Geoffrey W. Bromiley: Theological Dictionary of the New Testament, 10 vols., WM. B. Eerdmans, Grand Rapids-Michigan, 1967.

LÉON-DUFOUR, X., Dictionnaire du Nouveau Testament, Seuil, Paris, 1975; trad. it. Pietro Crespi: Dizionario del Nuovo Testamento, Quiriniana, Brescia, 1978.

METZGER, B. M., A Textual Commentary on the Greek New Testament, United Bible Societies, London-New York, edição revisada, 1975.

MOULTON, H. K., The Analytical Greek Lexicon Revised, Zondervan, Grand Rapids-Michigan, 1978

MOULTON, W. F., GEDEN, A. S., MOULTON., H. K., Concordance to the Greek New Testament, T e T Clark, Edinburgh, $1985^{5}$.

NESTLE, E., ALAND, K., Novum Testamentum Graece, Deutsche Bibelgesellschaft, Stuttgart, $1979^{26}$.

TISCHENDORF, C., Novum Testamentum Graece, 8th ed. 3 volumes, Giesecke \& Devrient, Leipzig, 1869.

ZERWICK, M., GROSVENOR, M., A Grammatical Analysis of the Greek New Testament, PIB, Roma, 1981.

ZERWICK, M., Biblical Greek, trad. ing. do original latino Graecitas Bíblica, por Joseph Smith, PIB, Roma, 1963.

ALLO, E. B., Saint Jean - L'Apocalypse, Etudes Bibliques. Gabalda, Paris, 1920.

BOISMARD, M. E., L'Apocalypse, BJ, Cerf, Paris, 1950.

BONSIRVEN, J., L'Apocalypse de Saint Jean, VS 16, Beauchesne, Paris, 1951.

BORING, M. E., The Theology of Revelation - 'The Lord our God the Almighty Reigns', Int 40(1986) 257-269.

BULlingER, E. W., Commentary on Revelation, 3d. Ed. Revised \& Corrected. London: Eyre \& Spottiswood, 1935. Reprint Edition. Grand Rapids: Kregel, 1984.

CHARLES, R. H., A Critical an Exegetical Commentary on the Revelation of St. John, 2 volumes, ICC, T \& T Clark, Edinburgh, 1920.

CHARLES, R. H., Revelation, 2 vols., T e T Clark, Edinburgh, 1920. 
COLlins, A. Y., The Apocalypse, New Testament Message 22, Michael Galzier, Wilmington, 1979.

COLLINS, A. Y., The Revelation of John: An Apocalyptic Response to a Social Crisis, CurTM 8(1981) 4-12.

COLLINS A. Y., Review of 'Revelation - Introduction, Translation and Commentary' by J. M. Ford, in CBQ 38(1976) 55-557.

COLLINS, A. Y., Review of 'L'Apocalypse de Saint Jean' by Pierre Prigent, in CBQ(1983) 504-506.

COTHENET, E. et alli, Les Ecrits de Saint Jean et l'Epitre aux Hébreux, Desclée, Paris, 1984.

CORSANI, B, Apocalisse di Giovanni: scritto apocalittico o profetico? BibOr 17(1975) 153-268.

CORSINI, E., Apocalisse Prima e Dopo, Soceitá Editrice Internazionale, Torino, 1980.

EGGER, W., Methodenlehre zum Neuen Testament, trad. it. Gianfranco Forza: Metodologia del Nuovo Testamento, ed. Dehoniane, Bologna, 1989.

FIORENZA, E. S., The Book of Revelation - Justice and Judgment, Fortress Press, Philadelphia, 1985.

FORD, J. M., Revelation - Introduction, Translation and Commentary, AB 38, Garden City, Doubleday, 1975.

FORD, J. M., 'For the Testimony of Jesus is the Spirit of Prophecy' (Rev 19,10), IrTheolQuart 42(1975) 284-291.

KIDDLE, M., The Revelation of St. John, Moffat New Testament Commentary, Hodder \& Stoughton, London, 1940.

LAMPE, G.W.H., 'The Testimony of Jesus is the Spirit of Prophecy' (Rev 19,10), in Weinrich C. William, The New Testament Age. Essays in Honor of Bo Reicke, Mercer, 1984, 244-258.

MAZZAFFERI, F., 'Martyria Iêsou' Revised, BibTrans 39(1988) 114-122.

LOHMEYER, E., Die Offenbarung des Johannes, 2d. ed. HNT 16, J.C.B. Mohr (Paul Siebeck), Tübingen, 1953.

LOHSE, E., Die Offenbarung des Johannes, NTD 11, Vandenhoeck \& Ruprecht, Goettingen, 1983.

LOISY, A., L'Apocalypse de Jean, Emile Nourry, Paris, 1923.

MONTAGNINI, F., Problemi dell'Apocalisse in alcuni studi degli ultimi anni, RivB 11(1963) 400-424.

MONTGOMERY, J. A., The Education of the Seer of the Apocalypse, JBL 45(1926) 70-80.

MOORE, H., The Book of Revelation, IBS 9(1987) 158-174.

MOUNCE, R. H., The Book of Revelation, NICNT 17, Grand Rapids, William B. Eerdmans, 1977. 
MASSYNGBERDE, J. F., Revelation, The Anchor Bible, Doubleday S. Garden City, New York, 1975.

PRIGENT, P., L'Apocalypse de Saint Jean, Delachaux et Niestlé, LausanneParis, 1981; trad. it. Piero Brugoli: L'Apocalisse di S. Giovanni, Borla, Roma, 1985.

SAlGUERO, J., Epístolas Católicas - Apocalipsis, Biblia Comentada 7, Biblioteca de Autores Cristianos, Madrid, 1965.

SHEA, W. H., Revelation 5 and 19 as Literary Reciprocals, AndUnivSemStud 22(1984) 249-257.

STRAND, K. A., The 'Victorius-Introduction' Scenes in the Visions in the Book of Revelation, AndUnivSemStud 25(1987) 267-288.

RUIZ, J. P., Ezekiel in the Apocalypse: The Transformation of Prophetic Language in Revelation 16,17-19,10, ed. Peter Lang, Frankfurt, New York, Paris, 1989.

RUSSELL, D. S., The Method and Message of Jewish Apocalyptic, SCM Press, London, 1964.

SWETE, H. H., The Apocalypse of St. John, Macmillan, London, $1907^{2}$.

VANHOYE, A., L'utilisation du livre d'Ezéchiel dans l'Apocalypse, Bib 43(1962) 436-476.

VANNI, U., Apocalisse: Esegese dei Brani Scelti, apostilas, fasc. III e VI, Gregoriana, Roma, Ano Acadêmico 1986-87; 1989-90.

VANNI, U., Apocalisse - Ermeneutica, Esegesi, Telogia, RivBSup 17, Dehoniane, Bologna, 1988.

VANNI, U., Apocalisse e Antico Testamento - Una Sinossi, PIB, Roma, 1984.

VANNI, U., La Struttura Letteraria dell'Apocalisse, 2nd ed. Aloisiana 8a., Morcelliana, Brescia, 1980.

VANNI, U., Gli apporti specifici dell'analise letteraria per l'esegesi e l'attualizzazione ermeneutica dell'Apocalisse, RivB 28(1980) 319-335.

VANNI, U., L'assemblea ecclesiale 'soggetto interpretante' dell'Apocalisse, RasT 23(1982) 497-513.

VANNI, U., Beati gli invitati alla cena delle nozze dell'Agnello (Ap 19,9): la speranza nell'Apocalisse, ParSpV 9(1984) 227-242.

VASSILIADIS, P., The Translation of 'martyria Iêsou' in Revelation, BT 36(1985) 129-134.

WIKENHAUSER, A., Die Offenbarung des Johannes, $3^{\mathrm{a}}$ edição revisada; F. Pustet, Regensburg, 1959; trad. it. Felice Montagnini: L'Apocalisse di Giovanni, Morceliana, Brescia, 1960. 